\title{
Ruminal and postruminal digestion of dietary protein and starch in steers: 2. Multivariate model prediction of non-ammonia nitrogen and starch passage and digestibility
}

\author{
H.H. Meissner* \\ Animal Nutrition and Animal Products Institute, Private Bag X2, Irene, 0062 Republic of South Africa \\ D.V. Paulsmeier \\ Department of Animal and Wildlife Sciences, University of Pretoria, Pretoria, 0002 Republic of South Africa
}

K-J. Leeuw and C.M. Coetzer

Animal Nutrition and Animal Products Institute, Private Bag X2, Irene, 0062 Republic of South Africa

Received 21 August 1995; accepted 26 February 1997

\begin{abstract}
Multivariate prediction models were developed from the results of three divergent trials with multicannulated steers. Diets differed in composition and physical structure. Energy contents varied from 10 to $13 \mathrm{MJ} \mathrm{ME} / \mathrm{kg} \mathrm{DM}$, starch from 20 to $62 \%$, CP from 102 to $155 \mathrm{~g} / \mathrm{kg} \mathrm{DM}$ and RDP from 60 to $85 \%$. In the first trial, diets were compiled from byproducts of the milling industry; in the second, maize meal was the major component and in the third high and normal lysine maize cultivars were fed either whole or rolled. Feeding levels were controlled or $a d$ libitum, varying between 65 to $95 \mathrm{~g} \mathrm{DM} / \mathrm{kgW}^{0.75} / \mathrm{d}$. With more starch in the diet, proportionally more passed to and was digested in the lower digestive tract. More starch tended to pass into the duodenum with lower RDP in the diet, but the effect was indirect through a reduction in the proportion OM which was apparently digested in the rumen $\left(O M D_{R}\right)$. NAN passage and digestion in the lower digestive tract were negatively associated with starch content of the diet. This effect was apparently rumen $\mathrm{pH}$ related, where high starch fermentation in the rumen lowered $\mathrm{pH}$ probably to the detriment of microbial protein production. NAN passage to the duodenum was associatecl positively with $N$ intake or protein content of the diet and negatively with $O M D_{R}$. RDP level in the diet per se did not affect the amount of NAN passing to the duodenum, but its interaction with $O M D_{R}$ was highly significant. Thus, with lower RDP levels, $O \mathrm{OM}_{R}$ was less, resulting in more NAN passing to the duodenum. Multivariate models predicted NAN and starch passage to the lower digestive tract with an $r^{2}$ between 0.89 and 0.97 and SDs of $15 \mathrm{~g} \mathrm{NAN} / \mathrm{d}$ and $60 \mathrm{~g} \mathrm{starch} / \mathrm{d}$. Non-intake associated differences between steers in amino acid and glucose availability at the duodenum was substantial, explaining partly the vast difference in feedlot performance of individual steers.
\end{abstract}

Meervoudige-veranderlike voorspellingsmodelle is ontwikkel vanaf resultate van drie uiteenlopende proewe met rumen- en duodenaalgefistuleerde osse. Die diëte het in samestelling en fisiese vorm verskil. Energie-inhoud het tussen 10 en 13 MJ ME/kg DM gevarieer, stysel tussen 20 en $62 \%$, RP tussen 102 en $155 \mathrm{~g} / \mathrm{kg}$ DM en RDP tussen 60 en $85 \%$. Die diëte in die eerste proef is saamgestel met neweprodukte van die maalbedryf, die in die tweede proef het mieliemeel as die hoofkomponent bevat en in die derde proef is hoë en normale lisien mielietipes heel of gerol gevoer. Voedingspeil het tussen 65 en $95 \mathrm{~g} \mathrm{DM} / \mathrm{kg} \mathrm{W} \mathrm{W}^{0.75} / \mathrm{d}$ gevarieer, laasgenoemde was ad libitum. Op diëte wat meer stysel bevat het, het verhoudelik meer stysel na die laer spysverteringskanaal gevloei en daar verteer. Op diëte met laer RDP \% was daar ' $n$ neiging tot meer styselvloei na die duodenum, maar die effek was indirek, veroorsaak deur ' $n$ afname in persentasie $O M$ wat skynbaar in die rumen verteer het $\left(O M V_{R}\right)$. NAN-vloei en -vertering in die laer spysverteringskanaal was negatief gekorreleerd met styselinhoud van die dieet. Dit kan skynbaar toegeskryf word aan lae rumen $\mathrm{pH}$ met hoë styselvertering wat mikrobe-proteïenproduksie benadeel. NAN-vloei na die duodenum was positief gekorreleerd met $\mathrm{N}$-inname en proteïeninhoud van die dieet, maar negatief met $\mathrm{OMV}_{\mathrm{R}}$. RDP-persentasie in die dieet per se het nie NAN-vloei na die duodenum beïnvloed nie, maar wel die interaksie tussen RDP en $O M V_{R}$. Byvoorbeeld, by laer RDP-waardes was $\mathrm{OMV}_{\mathrm{R}}$ laer, wat NAN-vloei na die duodenum bevoordeel het. Meervoudige-veranderlike modelle het NAN- en styselvloei na die laer spysverteringskanaal voorspel met ' $n r^{2}$ van tussen 0.89 en 0.97 en SA's van $15 \mathrm{~g}$ NAN/d en $60 \mathrm{~g}$ stysel/d. Nie-inname verwante verskille tussen osse in aminosuur- en glukosebeskikbaarheid by die duodenum was groot, wat onder andere die groot verskille tussen individue in voerkraalprestasie verklaar.

Keywords: Prediction model, non-ammonia nitrogen, starch, digestion, steers

*To whom correspondence should be addressed

\section{Introduction}

Although the volatile fatty acids (VFA) produced in the rumen are important contributors to the energy supply for growth of feedlot steers, amino acid and glucose uptake from the small intestine may be quantitatively and qualitatively even more important. This results firstly because, since amino acids are utilized for protein synthesis and gluconeogenesis, amino acid availability in the small intestine correlates better with growth rate than VFA availability in the rumen (MacRae \& Ulyatt, 1974). Secondly, glucose is used 10 to $40 \%$ more efficiently when absorbed from the small intestine rather than as VFA from the rumen (Leng, 1982; Owens et al., 1984), 
although results in practice do not always support this (Theurer, 1986). Thus, the availability of amino acids and glucose in the small intestine and the factors influencing it, are of interest.

More amino acids are expected to be available in the small intestine when ruminal degradation of dietary protein is lower (Meissner \& Du Plessis, 1992), however, this is not always true (Meissner \& Du Preez, 1996). Depending on the feedstuffs used, ruminal $\mathrm{pH}$ and ruminal turnover, the amount of microbial amino acids produced on a diet with higher RDP may be higher than on a diet with lower RDP; the net result is similar amounts at the duodenum. Meissner \& Du Preez (1996) found $\mathrm{N}$ intake and the proportion OM fermented in the rumen (an inverse function of rumen turnover) were the major factors affecting non-ammonia nitrogen (NAN) passage to the duodenum, whereas protein degradation $(60 \%$ vs $70 \%$ RDP) did not have a significant effect. With more starch in the diet, proportionally more starch was digested postruminally. Meissner \& Du Plessis (1992) furthermore found that starch passage to the duodenum was increased by lower RDP in the diet. Hence, effective prediction of NAN and starch availability in the small intestine requires a multifactorial approach with extensive data sets. The data sets of Meissner \& Du Plessis (1992) and Meissner \& Du Preez (1996) were therefore supplemented with those of Leeuw and Coetzer (unpublished) in order to obtain divergent dietary conditions which could allow robust tests and to develop reliable prediction equations.

\section{Procedures}

\section{Data sets}

The experiments of Meissner \& Du Preez (1996), Meissner \& Du Plessis (1992) and Leeuw and Coetzer (unpublished) are referred to in the text as Exp. 1, 2 and 3, respectively.

In Exp. 1, eight ruminal and duodenally fistulated steers were fed in a Latin square design. In the first $4 \times 4$ Latin square two protein contents (i.e., 105 and $125 \mathrm{~g} \mathrm{CP} / \mathrm{kg} \mathrm{DM}$ ) were fed, each at 60 and $70 \%$ RDP. The dietary energy concentration was $10.0 \mathrm{MJ} \mathrm{ME} / \mathrm{kg}$ DM. In the second $4 \times 4$ Latin square the dietary energy concentration was $12.5 \mathrm{MJ} \mathrm{ME} / \mathrm{kg}$ $\mathrm{DM}$, the two protein contents were raised to 135 and $155 \mathrm{CP} /$ $\mathrm{kg}$ DM respectively, to obtain the same protein to energy ratios as in the first trial. The RDP levels were also 60 and $70 \%$. All diets were fed in four equal portions each day at a level of $100 \mathrm{~g}$ air dry feed per kg metabolic mass $\left(\mathrm{W}^{0.75}\right)$. The diets consisted of different proportions of sorghum, maize, maize and wheat byproducts, cottonseed hulls, lucerne pellets, salt, minerals, vitamins, $\mathrm{CaCO}_{3}$ as buffer, an antibiotic and an ionophore. More details are given by Meissner \& Du Preez (1996).

Protein degradability was determined by nylon bag technique. Digesta passage was measured by the double marker technique with Na-dichromate as particulate and Co-EDTA as fluid marker, respectively. Passage and disappearance of OM, N, starch and NAN were determined between mouth and duodenum and between duodenum and faeces. Measurements in the rumen included $\mathrm{pH}$ and $\mathrm{NH}_{3}-\mathrm{N}$ concentration.

In Exp. 2, twelve steers were fistulated in the rumen and duodenum and allocated factorially to one of three dietary treatments. The treatments differed in daily supply of CP and
$\mathrm{RDP}$, effected by the following protein supplements: $1.44 \%$ urea (117 g CP/kg DM; 74\% RDP), 0.96\% urea (102 g CP/kg $\mathrm{DM} ; 70 \% \mathrm{RDP})$ and $0.47 \%$ urea plus $5.7 \%$ fish meal (118 g $\mathrm{CP} / \mathrm{kg} \mathrm{DM} ; 62 \% \mathrm{RDP})$. The remainder of each diet consisted of $11 \%$ cottonseed hulls, about $80 \%$ maize meal, molasses, a premix containing vitamins, trace minerals, salt, $\mathrm{NaHCO}_{3}$, $\mathrm{KCl}$, an ionophore and an antibiotic, and $\mathrm{CaCO}_{3}$. The $\mathrm{ME}$ content of the diets was approximately $11.7 \mathrm{MJ} / \mathrm{kg} \mathrm{DM}$ and the diets were fed in four equal portions each day at a level of $80 \mathrm{~g} \mathrm{DM} / \mathrm{kg} \mathrm{W}^{0.75}$.

The same markers and measurements as described for Exp. 1 applied for Exp. 2. See details in Meissner \& Du Plessis (1992).

In Exp. 3, eight steers were fitted with ruminal, duodenal and ileal cannulae. They were allocated to one of four dietary treatments in a Latin square design and fed ad libitum. The dietary treatments consisted of different maize cultivars. These were a high-lysine cultivar, which was fed either whole or rolled, a soft normal-lysine cultivar fed whole, and a hard normal-lysine cultivar fed whole. The diets consisted of $87 \%$ maize to which was added $30 \mathrm{~g} / \mathrm{kg}$ of a urea-mineral mixture, $50 \mathrm{~g} / \mathrm{kg}$ molasses and $50 \mathrm{~g} / \mathrm{kg}$ maize-crop residue. The urea-mineral mixture consisted of urea, $\mathrm{CaCO}_{3}, \mathrm{DiCaP}$, salt, $\mathrm{NaHCO}_{3}, \mathrm{~K}_{2} \mathrm{SO}_{4}$, vitamins, trace minerals, an antibiotic and an ionophore. The CP content of the diets averaged $138 \mathrm{~g} / \mathrm{kg}$ DM, about $30 \%$ was contributed by urea, and the ME content, calculated from the apparent digestibilities, was $>13 \mathrm{MJ} / \mathrm{kg}$ DM.

Chrome oxide was used as an indigestible marker to determine digesta flow and purine to distinguish microbial $\mathrm{N}$ in total duodenal N. RDP values of whole maize cannot be effectively determined by nylon bag technique; these were estimated from the proportion of microbial $\mathrm{N}$ in total $\mathrm{N}$ at the duodenum (range 70 to $85 \%$ ). As with Exp. 1 and 2, passage and disappearance of $\mathrm{OM}, \mathrm{N}$, starch and NAN were calculated between mouth and duodenum and between duodenum and faeces. Rumen $\mathrm{pH}$ and $\mathrm{NH}_{3}-\mathrm{H}$ also were measured.

The most prominent differences between experiments were in feedstuffs and physical structure of the diets, ME contents (10 to $>13 \mathrm{MJ} / \mathrm{kg} \mathrm{DM}$ ), starch contents (20 to $62 \%$ ), CP contents (102 to $155 \mathrm{~g} / \mathrm{kg} \mathrm{DM}$ ) and RDP levels (60 to $85 \%$ ).

\section{Statistical analyses}

Differences between treatments within experiments were established by the General Linear Models (GLM) Program of SAS (1985), employing the prescribed methods for Latin squares and factorial designs. NAN and starch passage to the duodenum and postruminal digestion were predicted by multivariate model building, where the contribution of factors and their interaction were tested with the stepdown procedure of GLM. Since significant contributions to the overall variation in dependent variable accounted for were very small at $p$ $\leq 0.05$, only contributions at $p \leq 0.01$ were included in the final models. Prediction models of NAN passage were scrutinized in plots of observed data points $v s$ predicted data points.

\section{Results}

Intake, passage and disappeareance of OM, starch and NAN in the digestive tract are displayed in Tables 1,2 and 3 for Exp. 1, 2 and 3, respectively. Intake of OM did not differ sig- 
Table 1 Intake, passage and disappearance of OM, starch and nitrogenous substances in the digestive tract of steers fed diets of byproducts of the milling industry, and formulated to contain two levels of respectively energy, crude protein and RDP (Exp. 1)

\begin{tabular}{|c|c|c|c|c|c|c|c|}
\hline \multirow[b]{2}{*}{ Item } & \multicolumn{2}{|c|}{$\mathrm{ME} \mathrm{MJ} / \mathrm{kg} \mathrm{DM}$} & \multicolumn{2}{|c|}{ Crude protein, $\%$} & \multicolumn{2}{|c|}{ RDP, $\%$} & \multirow[b]{2}{*}{$S D$} \\
\hline & 12.5 & 10.0 & 14.0 & 12.0 & 70 & 60 & \\
\hline \multicolumn{8}{|l|}{ Intake } \\
\hline $\mathrm{OM}, \mathrm{kg} / \mathrm{d}$ & 8.02 & 8.09 & 8.06 & 8.05 & 8.13 & 7.99 & 0.22 \\
\hline Starch, kg/d & $2.12^{\mathrm{b}}$ & $1.80^{\mathrm{a}}$ & $1.81^{\mathrm{c}}$ & $2.11^{\mathrm{d}}$ & 1.90 & 2.02 & 0.16 \\
\hline $\mathrm{N}, \mathrm{g} / \mathrm{d}$ & $207^{b}$ & $164^{\mathrm{a}}$ & $199^{d}$ & $172^{\mathrm{c}}$ & 187 & 183 & 6.09 \\
\hline Rumen $\mathrm{pH}$ & $6.23^{\mathrm{a}}$ & $6.41^{\mathrm{b}}$ & 6.33 & 6.31 & $6.63^{\mathrm{f}}$ & $6.28^{c}$ & 0.11 \\
\hline $\begin{array}{l}\text { Rumen } \mathrm{NH}_{3}-\mathrm{N} \text {, } \\
\mathrm{mmol} / \mathrm{l}\end{array}$ & $8.37^{\mathrm{b}}$ & $7.08^{\mathrm{a}}$ & 8.03 & 7.42 & $8.74^{\mathrm{f}}$ & $6.75^{\mathrm{e}}$ & 1.14 \\
\hline \multicolumn{8}{|c|}{ Disappearance before duodenun } \\
\hline $\mathrm{OM}, \mathrm{kg} / \mathrm{d}$ & $459^{\mathrm{a}}$ & $5.39^{\mathrm{b}}$ & 4.89 & 5.09 & 5.09 & 4.89 & 0.29 \\
\hline $\mathrm{OM}, \%$ of intake & $57.2^{\mathrm{a}}$ & $66.6^{\mathrm{b}}$ & 60.7 & 63.2 & 62.6 & 61.0 & 2.57 \\
\hline Starch, kg/d & 1.71 & 1.56 & $1.51^{\mathrm{c}}$ & $1.77^{\mathrm{d}}$ & 1.61 & 1.67 & 0.16 \\
\hline Starch, \% of intake & $80.7^{\mathrm{a}}$ & $86.7^{b}$ & 83.4 & 83.9 & 84.7 & 82.7 & 3.81 \\
\hline $\mathrm{N}, \mathrm{g} / \mathrm{d}$ & 41.2 & 35.5 & 40.1 & 36.6 & 42.0 & 34.7 & 11.2 \\
\hline $\mathrm{N}, \%$ of intake & 19.9 & 21.6 & 20.2 & 21.3 & 22.5 & 19.0 & 5.28 \\
\hline \multicolumn{8}{|l|}{ Passage to duodenum } \\
\hline $\mathrm{OM}, \mathrm{kg} / \mathrm{d}$ & $3.43^{\mathrm{b}}$ & $2.70^{\mathrm{a}}$ & 3.17 & 2.96 & 3.04 & 3.09 & 0.20 \\
\hline Starch, kg/d & $0.41^{\mathrm{b}}$ & $0.24^{\mathrm{a}}$ & 0.30 & 0.34 & 0.29 & 0.35 & 0.07 \\
\hline NAN, $g / d$ & $164^{b}$ & $125^{\mathrm{a}}$ & $154^{d}$ & $133^{c}$ & 143 & 145 & 8.29 \\
\hline \multicolumn{8}{|c|}{ Disappearance after duodenum } \\
\hline $\mathrm{OM}, \mathrm{kg} / \mathrm{d}$ & $1.68^{\mathrm{b}}$ & $0.96^{\mathrm{a}}$ & 1.41 & 1.23 & 1.31 & 1.33 & 0.20 \\
\hline $\mathrm{OM}, \%$ of intake & $20.9^{b}$ & $11.9^{\mathrm{a}}$ & 17.5 & 15.3 & 16.1 & 16.6 & 2.59 \\
\hline Starch, $\mathrm{kg} / \mathrm{d}$ & $0.29^{\mathrm{b}}$ & $0.12^{\mathrm{a}}$ & 0.18 & 0.23 & 0.18 & 0.22 & 0.07 \\
\hline Starch, \% of intake & $13.7^{\mathrm{b}}$ & $6.67^{\mathrm{a}}$ & 9.94 & 10.9 & 9.47 & 10.9 & 3.68 \\
\hline NAN, g/d & $119^{\mathrm{b}}$ & $83.1^{\mathrm{a}}$ & $112^{\mathrm{d}}$ & $90.1^{\mathrm{c}}$ & 100 & 102 & 9.38 \\
\hline NAN, $\%$ of $N$ intake & 57.5 & 50.7 & 56.3 & 52.4 & 53.5 & 55.7 & 5.28 \\
\hline
\end{tabular}

Values with different superscripts between energy contents $(a, b)$, protein contents (c,d) and RDP levels (e,f) differ $(p \leq 0.05)$

nificantly between energy and protein contents in Exp. 1, as planned (Table 1). Starch intake differed because the starch contents of the 12.5 MJ ME $/ \mathrm{kg}$ DM (high energy) diets were higher than the starch contents of the $10.0 \mathrm{MJ} \mathrm{ME} / \mathrm{kg} \mathrm{DM}$ (low energy) diets. Intake also differed between protein contents because feedstuffs (energy sources) with higher protein contents often have lower starch contents owing to starch extraction. Nitrogen intakes differed between energy and protein contents but not between RDP-values as planned. In the rumen, $\mathrm{pH}$ was lower with the high energy diets and the lower RDP-values. The latter may be explained by lower $\mathrm{NH}_{3}-\mathrm{N}$ concentrations for the $60 \%$ RDP $v s$ the $70 \%$ RDP diets.

Proportionally more OM and starch disappeared before the duodenum on the low energy diets. Protein contents and RDP $\%$ did not have a significant effect on OM disappearance or on starch disappearance if corrected for differences in starch intake. Nitrogen disappearance before the duodenum was not significantly affected by either energy content of the diet, protein content or RDP \% (Table 1). In contrast, the amount of NAN flowing to the duodenum was higher on the high energy
Table 2 Intake, passage and disappearance of OM, starch and nitrogenous substances in the digestive tract of steers fed maize diets differing in crude protein and RDP of the supplement (Exp. 2)

\begin{tabular}{|c|c|c|c|c|}
\hline Item & $\begin{array}{l}1.44 \% \text { urea } \\
\text { (74\% RDP) }\end{array}$ & $\begin{array}{l}0.96 \% \text { urea } \\
(70 \% \text { RDP) }\end{array}$ & $\begin{array}{c}0.47 \% \text { urea } \\
5.7 \% \text { fish meal } \\
(62 \% \text { RDP })\end{array}$ & SD \\
\hline \multicolumn{5}{|l|}{ Intake } \\
\hline $\mathrm{OM}, \mathrm{kg} / \mathrm{d}$ & 5.68 & 5.70 & 5.51 & 0.21 \\
\hline Starch, $\mathrm{kg} / \mathrm{d}$ & 3.49 & 3.50 & 3.22 & 0.13 \\
\hline $\mathrm{N}, \mathrm{g} / \mathrm{d}$ & $118^{\mathrm{b}}$ & $103^{\mathrm{a}}$ & $116^{b}$ & 4.42 \\
\hline Rumen pH & 5.99 & 6.00 & 5.87 & 0.15 \\
\hline Rumen $\mathrm{NH}_{3}-\mathrm{N}, \mathrm{mmol} / \mathrm{l}$ & $17.4^{\mathrm{b}}$ & $16.1^{\mathrm{ab}}$ & $10.5^{\mathrm{a}}$ & 1.68 \\
\hline \multicolumn{5}{|c|}{ Disappearance before duodenum } \\
\hline $\mathrm{OM}, \mathrm{kg} / \mathrm{d}$ & $2.97^{\mathrm{ab}}$ & $3.30^{\mathrm{b}}$ & $2.55^{\mathrm{a}}$ & 0.19 \\
\hline OM, $\%$ of intake & $52.3^{\mathrm{ab}}$ & $57.9^{\mathrm{b}}$ & $46.3^{\mathrm{a}}$ & 1.54 \\
\hline Starch, $\mathrm{kg} / \mathrm{d}$ & $2.96^{\mathrm{b}}$ & $2.91^{\mathrm{b}}$ & $2.46^{\mathrm{a}}$ & 0.14 \\
\hline Starch, \% of intake & $84.8^{\mathrm{b}}$ & $83.1^{\mathrm{b}}$ & $76.4^{\mathrm{a}}$ & 1.95 \\
\hline$N, g / d$ & $24.6^{\mathrm{ab}}$ & $33.5^{\mathrm{b}}$ & $16.3^{\mathrm{a}}$ & 3.98 \\
\hline $\mathrm{N}, \%$ of intake & $20.8^{\mathrm{ab}}$ & $32.5^{\mathrm{b}}$ & $14.1^{\mathrm{a}}$ & 3.50 \\
\hline \multicolumn{5}{|l|}{ Passage to duodenum } \\
\hline $\mathrm{OM}, \mathrm{kg} / \mathrm{d}$ & $2.71^{\mathrm{ab}}$ & $2.39^{\mathrm{a}}$ & $2.98^{\mathrm{b}}$ & 0.11 \\
\hline Starch, $\mathrm{kg} / \mathrm{d}$ & $0.52^{\mathrm{a}}$ & $0.59^{\mathrm{ab}}$ & $0.76^{\mathrm{b}}$ & 0.06 \\
\hline NAN, $g / d$ & $89.6^{\mathrm{ab}}$ & $68.5^{\mathrm{a}}$ & $98.5^{\mathrm{b}}$ & 8.40 \\
\hline \multicolumn{5}{|c|}{ Disappearance after duodenum } \\
\hline $\mathrm{OM}, \mathrm{kg} / \mathrm{d}$ & 1.36 & 1.04 & 1.70 & 0.13 \\
\hline $\mathrm{OM}, \%$ of intake & $23.9^{\mathrm{ab}}$ & $18.2^{\mathrm{a}}$ & $30.9^{\mathrm{b}}$ & 2.67 \\
\hline Starch, $\mathrm{kg} / \mathrm{d}$ & $0.32^{\mathrm{a}}$ & $0.38^{\mathrm{a}}$ & $0.57^{\mathrm{b}}$ & 0.08 \\
\hline Starch, $\%$ of intake & $9.17^{\mathrm{a}}$ & $10.9^{\mathrm{a}}$ & $17.7^{\mathrm{b}}$ & 2.43 \\
\hline NAN, g/d & $62.4^{\mathrm{ab}}$ & $45.7^{\mathrm{a}}$ & $67.4^{\mathrm{b}}$ & 7.96 \\
\hline NAN, $\%$ of $N$ intake & $52.9^{\mathrm{ab}}$ & $44.4^{\mathrm{a}}$ & $58.1^{\mathrm{b}}$ & 7.43 \\
\hline
\end{tabular}

diets and higher protein contents, whereas RDP\% did not have a significant effect. Both OM and starch passage to the duodenum was higher on the high energy diet; that coincided with more $\mathrm{OM}$ and starch ( $\mathrm{kg}$ and \%) being digested in the lower digestive tract. Passage of OM and starch and their disappearance after the duodenum were, however, not significantly affected by protein content or RDP\%. More NAN was digested in the small intestine on the higher protein diets, but that could be explained hy the higher $\mathrm{N}$ intake. Again, RDP\% did not have a significant effect on NAN digestion or on the digestion of OM and starch.

In Exp. 2 (Table 2), $\mathrm{N}$ intake was similar on the high urea (1.44\%) diet and the fish meal diet, but $\mathrm{N}$ intake, as intended, was significantly lower with the low urea $(0.96 \%)$ diet. The difference in $\mathrm{N}$ intake and RDP \% was reflected in the rumen $\mathrm{NH}_{3}-\mathrm{N}$ levels, where the fish meal diet (62\% RDP) had the lowest level. Intake of OM and starch did not differ significantly between treatments. Also, rumen $\mathrm{pH}$ was similar.

Less OM, starch and $\mathrm{N}$ disappeared before the duodenum on the fish meal diet than on the urea diets (Table 2), although only the difference between the fish meal diet and the low urea diet was significant. As a result, more OM, starch and 
Table 3 Intake, passage and disappearance of OM, starch and nitrogenous substances in the digestive tract of steers fed different maize cultivars (Exp. 3)

\begin{tabular}{|c|c|c|c|c|c|}
\hline \multirow[b]{3}{*}{ Item } & \multicolumn{4}{|c|}{ Maize cultivar } & \multirow[b]{3}{*}{$S D$} \\
\hline & \multicolumn{2}{|c|}{ High-lysine } & \multirow{2}{*}{$\begin{array}{c}\text { Soft } \\
\text { normal } \\
\text { whole }\end{array}$} & \multirow{2}{*}{$\begin{array}{c}\text { Hard } \\
\text { normal } \\
\text { whole }\end{array}$} & \\
\hline & whole & rolled & & & \\
\hline \multicolumn{6}{|l|}{ Intake } \\
\hline $\mathrm{OM}, \mathrm{kg} / \mathrm{d}$ & 5.58 & 5.63 & 5.52 & 5.65 & 0.45 \\
\hline Starch, $\mathrm{kg} / \mathrm{d}$ & 3.64 & 3.58 & 3.53 & 3.55 & 0.33 \\
\hline $\mathrm{N}, \mathrm{g} / \mathrm{d}$ & 128 & 123 & 133 & 132 & 11.6 \\
\hline Rumen $\mathrm{pH}$ & 5.72 & 5.66 & 5.71 & 5.72 & 0.14 \\
\hline Rumen $\mathrm{NH}_{3}-\mathrm{N}, \mathrm{mmol} / \mathrm{l}$ & 5.21 & 5.85 & 4.64 & 4.64 & 0.58 \\
\hline \multicolumn{6}{|c|}{ Disappearance before duodenum } \\
\hline $\mathrm{OM}, \mathrm{k}, \mathrm{d}$ & 3.69 & 3.61 & 3.30 & 3.87 & 0.25 \\
\hline $\mathrm{OM}, \%$ of intake & 66.1 & 64.1 & 59.8 & 68.5 & 2.85 \\
\hline Starch, kg/d & 2.74 & 2.63 & 2.44 & 2.77 & 0.29 \\
\hline Starch, \% of intake & 75.3 & 73.5 & 69.1 & 78.0 & 3.40 \\
\hline $\mathrm{N}, \mathrm{g} / \mathrm{d}$ & 60.7 & 54.1 & 46.4 & 54.2 & 8.70 \\
\hline $\mathrm{N}, \%$ of intake & 47.4 & 44.0 & 34.9 & 41.1 & 5.20 \\
\hline \multicolumn{6}{|l|}{ Passage to duodenum } \\
\hline $\mathrm{OM}, \mathrm{kg} / \mathrm{d}$ & 1.88 & 2.02 & 2.22 & 1.78 & 0.29 \\
\hline Starch, kg/d & 0.87 & 0.94 & 1.06 & 0.78 & 0.14 \\
\hline NAN, g/d & 63.4 & 64.9 & 81.7 & 78.2 & 7.97 \\
\hline \multicolumn{6}{|c|}{ Disappearance after duodenum } \\
\hline $\mathrm{OM}, \mathrm{kg} / \mathrm{d}$ & 1.20 & 1.24 & 1.52 & 1.10 & 0.16 \\
\hline $\mathrm{OM}, \%$ of intake & 21.5 & 22.0 & 27.5 & 19.5 & 1.01 \\
\hline Starch, $\mathrm{kg} / \mathrm{d}$ & $0.67^{\mathrm{a}}$ & $0.70^{\mathrm{a}}$ & $0.91^{\mathrm{a}}$ & $0.60^{\mathrm{a}}$ & 0.11 \\
\hline Starch, \% of intake & 18.4 & 19.6 & 25.8 & 16.9 & 0.94 \\
\hline NAN, g/d & 44.1 & 44.2 & 59.3 & 52.0 & 5.60 \\
\hline NAN, $\%$ of $N$ intake & 34.5 & 35.9 & 44.6 & 39.4 & 4.92 \\
\hline
\end{tabular}

a,b Values in the same line with different superscripts differ $(p \leq 0.05)$

NAN passed to the duodenum on the fish meal diet than the urea diets and more were apparently digested. Noteworthy is the significant difference in starch digestion between the fish meal diet and the urea diets, whereas for NAN digestion the fish meal diet only differed significantly from the low urea diet. As with the results of Exp. 1 (Table 1), these results indicate that the major effect on NAN passage and digestion is due to protein level and not the degradability of protein.

In Exp. 3 (Table 3), more starch disappeared after the duodenum on the soft normal-lysine treatment, but the result was no longer significant when adjusted for difference in starch intake. There also appears to be a small difference between the high-lysine and normal-lysine cultivars in $\mathrm{N}$ transactions. Rumen $\mathrm{NH}_{3}-\mathrm{N}$ concentrations tended to be lower on the normal-lysine cultivars, with correspondingly lower $\mathrm{N}$ disappearance before the duodenum but more passage of NAN to the duodenum and digestion in the lower digestive tract.

In view of the main goal of the investigation i.e., to define factors influencing NAN and starch availability at the duodenum, it is of interest to compare results between experiments. The results show that with more starch in the diet, proportionally less is digested before the duodenum and more in the lower digestive tract: In Exp. 1 (Table 1), the low energy diet contained $20 \%$ starch; $86.7 \%$ was digested before the duodenum and $6.67 \%$ thereafter. The high energy diet contained $24 \%$ starch, $80.7 \%$ was digested before the duodenum and correspondingly $13.7 \%$ thereafter. In Exp. 2 (Table 2), the diets contained about $55 \%$ starch, and between 76 and $85 \%$ starch was digested before the duodenum and between 9.2 and $18 \%$ thereafter. The relatively small difference as compared to Exp. 1 may be due to comparatively lower intakes and therefore slower passage to the duodenum in Exp. 2. Noteworthy also is the higher starch digestion in the lower digestive tract on the fish meal (62\% RDP) diet compared to the urea (70-74\% RDP) diets. In Exp. 3 (Table 3), the diets contained 58 to $62 \%$ starch, 69 to $78 \%$ was digested before the duodenum and correspondingly 16.9 to $26 \%$ thereafter.

The difference in NAN digestion in the lower digestive tract shows the opposite trend to that of starch, although the relationship is not close, presumably owing to differences in protein level, RDP, intake and physical form of the diet. In Exp. 1, an average of 54 NAN as a percentage of $\mathrm{N}$ intake was digested in the lower digestive tract, in Exp. 2, 52\% and in Exp. 3, 39\%. Of further significance to NAN availability at the duodenum is rumen $\mathrm{pH}$, because that may affect microbial growth and protein production. Rumen $\mathrm{pH}$ was higher in Exp. 1 (6.32) than in Exp. 2 (5.95) and in Exp 3. (5.70). If the daily trend in rumen $\mathrm{pH}$ is considered (Figure 1), it is noteworthy that in Exp. 1 rumen pH never declined to below 6, in Exp. 2 it did for about $9 \mathrm{~h}$, and in Exp. 3 rumen pH was always below 6 .

Tables 4 and 5 show the prediction models for NAN passage to the duodenum as obtained by the stepdown procedure. Model A (Table 4) is based on N and starch intake, whereas Model B (Table 5) is based on protein and starch content of the diet. The final prediction models are those based on the combined data of Exp. 1, 2 and 3, but the corresponding equations for Exp. 1 only and for Exp. 1 and 2 combined, are also shown to illustrate that the partial contributions of influencing

Table 4 Prediction model A with data successively analysed for Exp. 1, Exp. 1+2 and Exp. 1+2+3. Dependent variable NAN passage to the duodenum $(\mathrm{g} / \mathrm{d})$

\begin{tabular}{llcccc}
\hline Exp. & Parameter & Value $\pm S D$ & $t$-value & PR $\geq \mathrm{F}$ & \\
\hline Exp. 1 & Intercept & $135.6 \pm 37.81$ & 3.59 & 0.0013 & $n=32$ \\
& N intake $(\mathrm{g} / \mathrm{d})$ & $0.573 \pm 0.103$ & 5.57 & 0.0001 & $r^{2}=0.727$ \\
& Starch intake $(\mathrm{kg} / \mathrm{d})$ & $-5.51 \pm 7.679$ & -0.717 & 0.4793 & $S D=15.9 \mathrm{~g} / \mathrm{d}$ \\
& RDP.OMD $_{\mathrm{R}}(\%)^{1}$ & $-0.017 \pm 0.004$ & -3.927 & 0.0005 & $\mathrm{CV} \%=11.01$ \\
& & & & & \\
Exp 1 + & Intercept & $116.4 \pm 28.90$ & 4.03 & 0.0003 & $n=43$ \\
& N intake (g/d) & $0.654 \pm 0.075$ & 8.73 & 0.0001 & $r^{2}=0.831$ \\
& Starch intake $(\mathrm{kg} / \mathrm{d})$ & $-10.78 \pm 4.334$ & -2.49 & 0.0172 & $S D=15.6 \mathrm{~g} / \mathrm{d}$ \\
& RDP.OMD $(\%)$ & $-0.014 \pm 0.003$ & -4.47 & 0.0001 & $C V \%=12.07$ \\
Exp 1 +2 & & & & & \\
+3 & Intercept & $118.1 \pm 15.22$ & 7.76 & 0.0001 & $n=74$ \\
& N intake $(\mathrm{g} / \mathrm{d})$ & $0.724 \pm 0.046$ & 15.78 & 0.0001 & $r^{2}=0.885$ \\
& Starch intake (kg/d) & $-12.70 \pm 1.885$ & -6.74 & 0.0001 & $S D=15.5 \mathrm{~g} / \mathrm{d}$ \\
& RDP.OMD $(\%)$ & $-0.017 \pm 0.002$ & -8.13 & 0.0001 & $\mathrm{CV} \%=15.19$ \\
\hline
\end{tabular}

${ }^{\mathrm{RDP} . O M D_{\mathrm{R}}}=$ Interaction between RDP (\%) and OM fermented in the rumen as a $\%$ of total $O M$ digested $\left(O M D_{R}\right)$ 
Table 5 Prediction model $B$ with data successively analysed for Exp 1, Exp 1+2 and Exp 1+2+3. Dependent variable NAN passage to the duodenum $(\mathrm{g} / \mathrm{d})$

\begin{tabular}{clcccc}
\hline Exp. & Parameter & Value $\pm \mathrm{SD}$ & $t$-value & $\mathrm{PR} \geq \mathrm{F}$ & \\
\hline Exp 1 & Intercept & $45.73 \pm 58.28$ & 0.785 & 0.4395 & $n=32$ \\
& Protein (\%) & $9.766 \pm 1.793$ & 5.447 & 0.0001 & $r^{2}=0.742$ \\
& OM intake (kg/d) & $7.706 \pm 4.842$ & 1.591 & 0.1232 & $S D=15.7 \mathrm{~g} / \mathrm{d}$ \\
& Starch (\%) & $-0599 \pm 0.683$ & -0.877 & 0.3881 & $\mathrm{CV} \%=10.92$ \\
& RDP.OMD $(\%)$ & $-0.015 \pm 0.005$ & -3.259 & 0.0030 & \\
Exp 1+2 & Intercept & $28.18 \pm 48.44$ & 0.582 & 0.5641 & $n=43$ \\
& Protein (\%) & $10.15 \pm 1.647$ & 6.163 & 0.0001 & $r^{2}=0.842$ \\
& OM intake (kg/d) & $8.458 \pm 4.150$ & 2.038 & 0.0485 & $S D=15.3 \mathrm{~g} / \mathrm{d}$ \\
& Starch (\%) & $-0.756 \pm 0.329$ & -2.296 & 0.0273 & $\mathrm{CV} \%=11.48$ \\
& RDP.OMD $(\%)$ & $-0.013 \pm 0.004$ & -3.623 & 0.0008 & \\
Exp & & & & & \\
$1+2+3$ & Intercept & $93.36 \pm 24.67$ & 3.78 & 0.0003 & $n=74$ \\
& Protein (\%) & $6.075 \pm 1.127$ & 5.39 & 0.0001 & $r^{2}=0.902$ \\
& OM intake (kg/d) & $10.66 \pm 1.893$ & 5.63 & 0.0001 & $S D=14.5 \mathrm{~g} / \mathrm{d}$ \\
& Starch (\%) & $-1.169 \pm 0.155$ & -7.56 & 0.0001 & $C V \%=14.7$ \\
& RDP.OMD $(\%)$ & $-0.017 \pm 0.002$ & -8.80 & 0.0001 & \\
\hline
\end{tabular}

variables are similar, although not always significant owing to an insufficient degrees of freedom. For example, in Model A starch intake was negatively associated with NAN passage for all three sets of data (Table 4). The regression coefficient of Exp. 1 data was, however, not significant, clearly because of insufficient degrees of freedom.

The $r^{2}$ and standard deviations (SD) of Model B were marginally better than those of Model A. Model B also is the preferred prediction equation because it is easy to determine the protein, starch and RDP contents of any particular feedlot diet and one can usually also anticipate the OM intake with comparative ease. Judging from the $t$-values, $\mathrm{N}$ intake or protein percentage and the interaction between RDP and percentage OM fermented in the rumen are the main contributors to the variation in NAN passage accounted for. It is of interest to note that the ME content of the diet and RDP \% per se or their interactions with other variables were not significantly associated with NAN passage. Thus, it appears that the influence of protein degradability was through its effect on rumen fermentation. With lower RDP levels proportionally less OM was digested in the rumen which apparently allows more protein to pass through to the duodenum (see also Table 8). Starch content or intake as suggested, might have been negatively associated with NAN passage to the duodenum because of the resulting lower $\mathrm{pH}$ (Figure 1 ) which presumably could depress microbial growth.

Generally, prediction models A and B of the combined data of Exp. 1, 2 and 3 fitted the data satisfactorily with an $r^{2}$ of about 0.9 and an $S D$ of $15 \mathrm{~g}$ NAN/day. The fit also was unbiased as indicated by the plots of observed $v s$ predicted NAN in Figure 2. Of concern, however, was the fact that RDP of whole maize in Exp. 3 could not be measured effectively by the nylon bag technique and therefore had to be predicted from microbial $\mathrm{N}$ at the duodenum. Hence, predictions from the models could be skewed. Therefore, the robustness of the

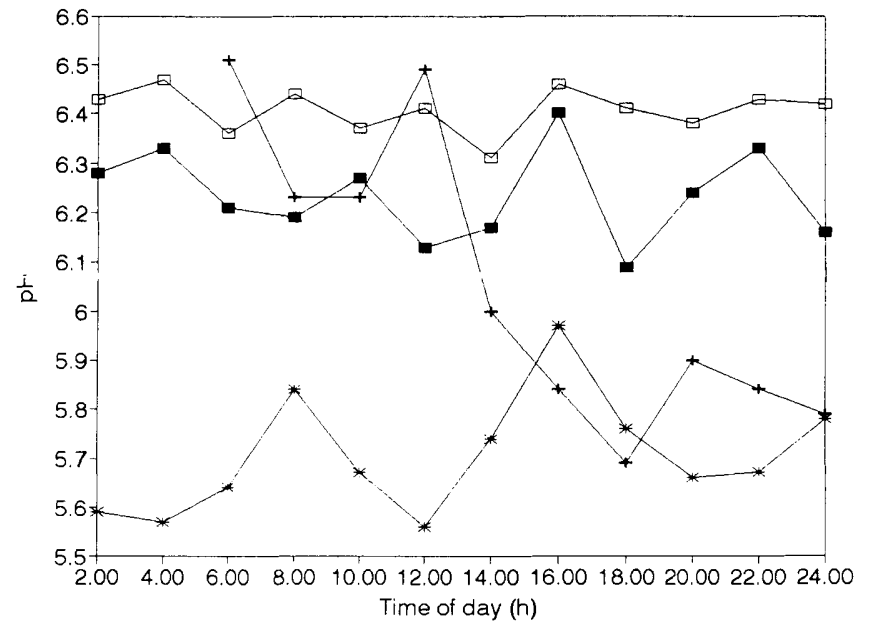

Figure 1 Daily variation in rumen $\mathrm{pH}$. - - Exp. $1 \mathrm{HE} ;-\square-$ Exp. 1 LE; - - Exp. 2; —*-Exp. 3.
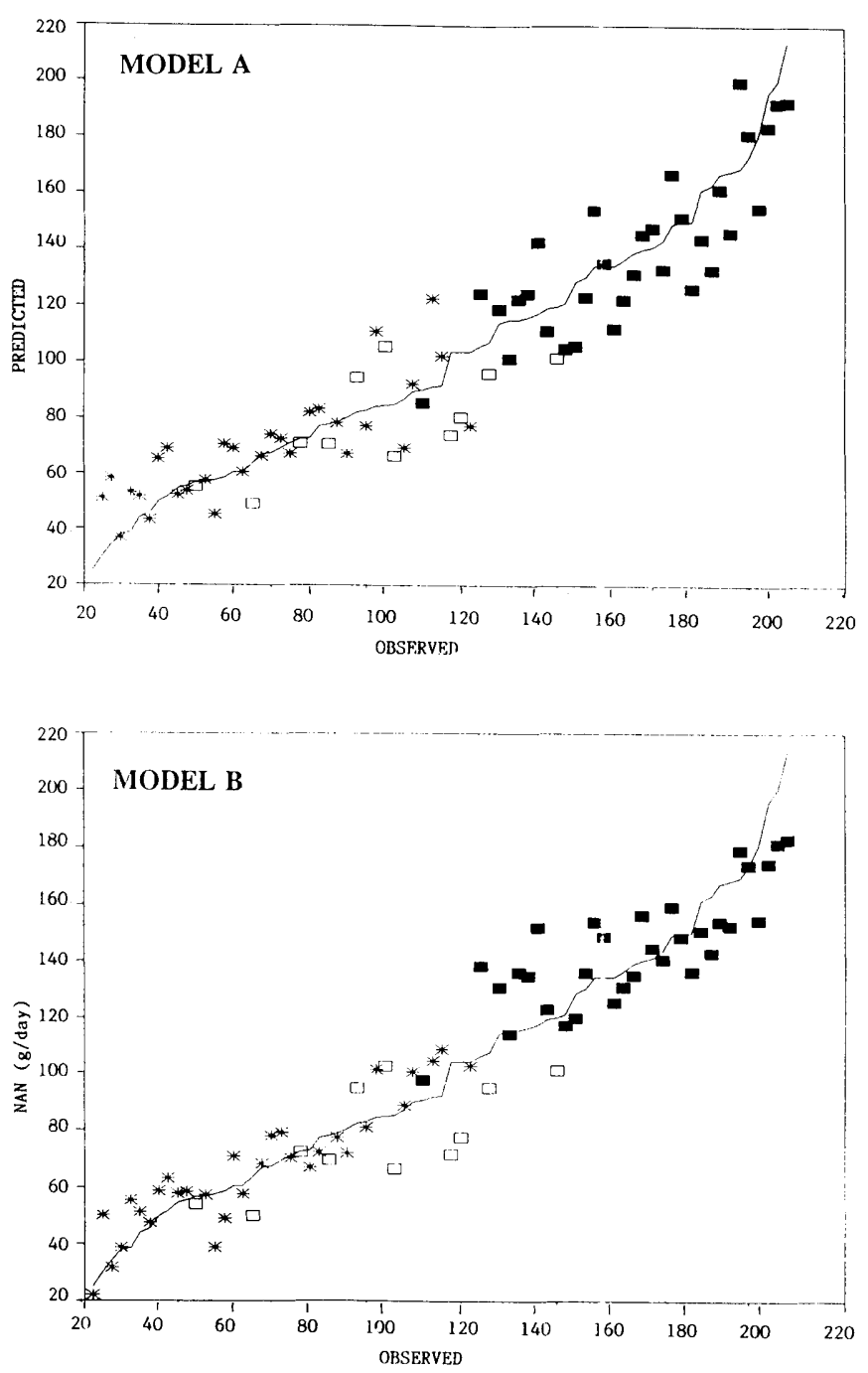

Figure 2 Predicted NAN (g/d) vs measured NAN observations. Model A is based on N and starch intake (see Table 4). Model B is based on dietary protein and starch contents and OM intake (see Table 5). - Observed $\square$ Exp. 1; $\square$ Exp. 2; * Exp. 3.

regression coefficients was tested if the RDP values in Exp. 3 were firstly decreased by 10 percentage units and secondly, again decreased by 10 percentage units but also allowing a 
$20 \%$ increase in NAN passage to the duodenum (Table 6 and Figure 3 ). These changes did not alter the regression coefficients significantly if the numerical value $\pm S D$ of the regression coefficients in Table 6 are compared with the corresponding regression coefficients in Tables 4 and 5 . The changes also did not have a major effect on the $r^{2}$ and $S D$, and the resulting alternative models still fitted the data sets satisfactorily (Figure 3 ). The test, therefore, suggests that the prediction models are robust and relatively accurate, and that the parameters contributing to the variability in NAN passage to the duodenum have a strong influence.

Table 6 Prediction Models $A$ and $B($ Exp. $1+2+3)$ when in Exp. 3 RPD values (Alternative model 1) were decreased by $10 \%$, and RDP and NAN values (Alternative model 2 ) were respectively decreased by $10 \%$ and increased by $20 \%$. Dependent variable NAN passage to the duodenum ( $\mathrm{g} / \mathrm{d}$ )

\begin{tabular}{|c|c|c|c|c|c|}
\hline Model & Parameter & Value $\pm S D$ & $t$-value & $\mathrm{PR} \geq \mathrm{F}$ & \\
\hline \multicolumn{6}{|l|}{ Model A } \\
\hline \multicolumn{2}{|c|}{ Altern. 1 Intercept } & $112.6 \pm 17.81$ & 6.32 & 0.0001 & $n=74$ \\
\hline & $\mathrm{N}$ intake $(\mathrm{g} / \mathrm{d})$ & $0.762 \pm 0.051$ & 15.06 & 0.0001 & $r^{2}=0.858$ \\
\hline & Starch intake $(\mathrm{kg} / \mathrm{d})$ & $-15.19 \pm 2.086$ & -7.28 & 0.0001 & $S D=17.2 \mathrm{~g} / \mathrm{d}$ \\
\hline & RDP.OMD ${ }_{\mathrm{R}}(\%)$ & $-0.016 \pm 0.003$ & -6.31 & 0.0001 & $C V \%=16.91$ \\
\hline \multirow[t]{4}{*}{ Altern. 2} & Intercept & $108.7 \pm 16.08$ & 6.076 & 0.0001 & $n=74$ \\
\hline & $\mathrm{N}$ intake $(\mathrm{g} / \mathrm{d})$ & $0.744 \pm 0.046$ & 16.30 & 0.0001 & $r^{2}=0.869$ \\
\hline & Starch intake $(\mathrm{kg} / \mathrm{d})$ & $-10.52 \pm 0.046$ & -5.59 & 0.0001 & $S D=15.6 \mathrm{~g} / \mathrm{d}$ \\
\hline & RDP.OMD $(\%)$ & $-0.016 \pm 0.002$ & -7.116 & 0.0001 & $C V \%=14.50$ \\
\hline \multicolumn{6}{|l|}{ Model B } \\
\hline \multirow[t]{5}{*}{ Altern. 1} & Intercept & $118.5 \pm 28.30$ & 4.186 & 0.0001 & $n=74$ \\
\hline & Protein $(\%)$ & $5.020 \pm 1.234$ & 4.067 & 0.0001 & $r^{2}=0.880$ \\
\hline & OM intake $(\mathrm{kg} / \mathrm{d})$ & $10.59 \pm 2.093$ & 5.24 & 0.0001 & $S D=15.4 \mathrm{~g} / \mathrm{d}$ \\
\hline & Starch (\%) & $-1.371 \pm 0.162$ & -8.44 & 0.0001 & $C V \%=15.14$ \\
\hline & RDP.OMD $\mathrm{R}(\%)$ & $-0.018 \pm 0.002$ & -7.70 & 0.0001 & \\
\hline \multirow[t]{5}{*}{ Altern. 2} & Intercept & $72.46 \pm 26.06$ & 2.780 & 0.0001 & $n=74$ \\
\hline & Protein $(\%)$ & $6.400 \pm 1.137$ & 5.63 & 0.0001 & $r^{2}=0.888$ \\
\hline & OM intake $(\mathrm{kg} / \mathrm{d})$ & $12.69 \pm 1.863$ & 6.81 & 0.0001 & $S D=14.2 \mathrm{~g} / \mathrm{d}$ \\
\hline & Starch $(\%)$ & $-0.982 \pm 0.150$ & -6.564 & 0.0001 & $C V \%=13.25$ \\
\hline & RDP.OMD ${ }_{\mathrm{R}}(\%)$ & $-0.018 \pm 0.002$ & -8.153 & 0.0001 & \\
\hline
\end{tabular}

Prediction models for starch passage to the duodenum and postruminal starch digestion were even more convincing than the NAN prediction models (Table 7), with $r^{2}$ of $0.97+$ and $\mathrm{CV}$ of 6 to $13 \%$. Rumen degradation of protein had a prominent influence in both models, as a factor per se and through an interaction with the proportion of starch digested in the rumen. As with NAN passage though, the effect of RDP was predominantly through its influence on rumen fermentation, indicating that with lower RDP more starch in general would be available in the lower digestive tract (see also Table 8). With these models, in contrast to the NAN models, ME content of the diet did make a significant contribution to the variation accounted for in starch passage or starch digestion. This may be explained partly by the fact that the higher ME diets also contained higher levels of starch.
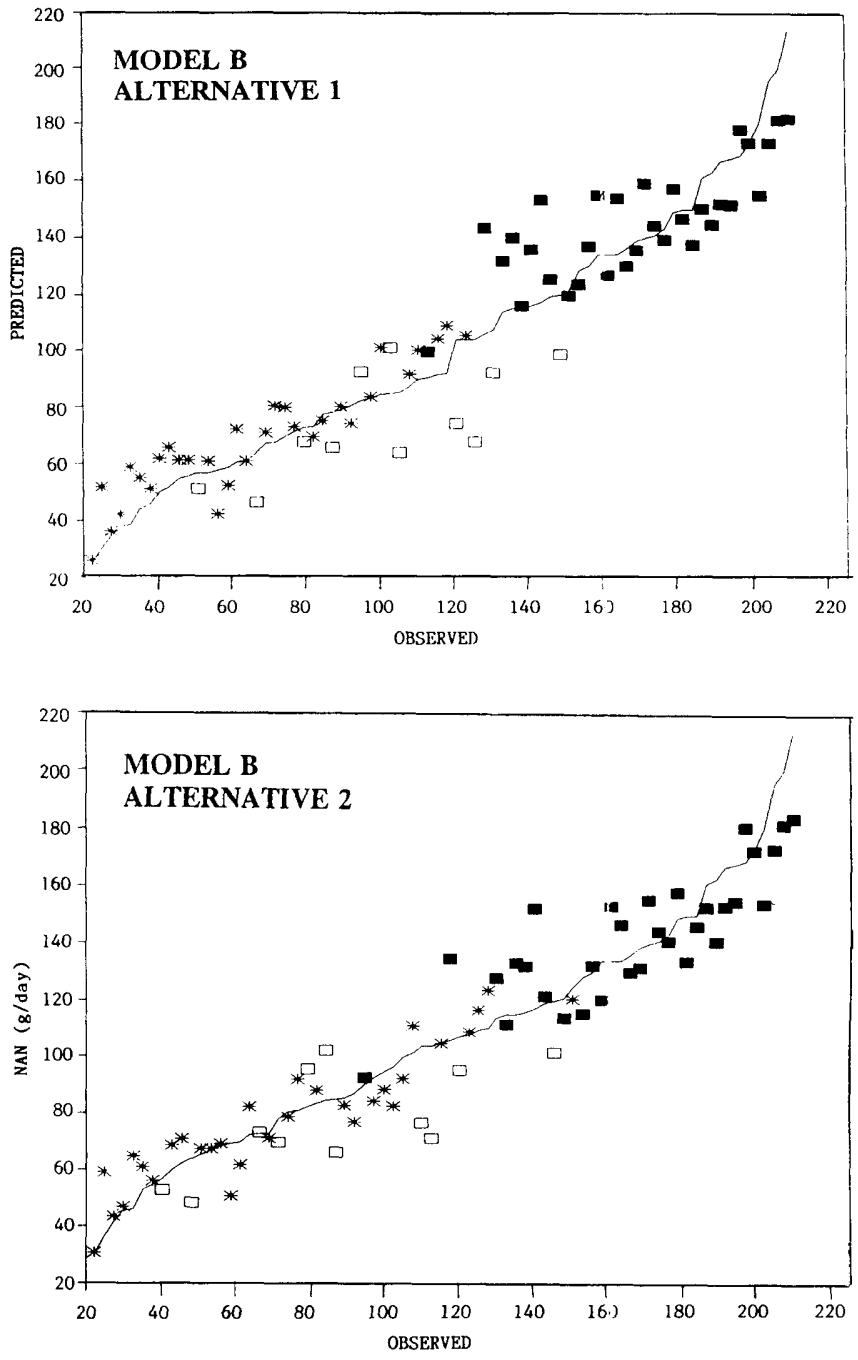

Figure 3 Predicted NAN (g/d) vs measured NAN observations. Model B: Alternative 1 - RDP levels were decreased by $10 \%$. Alternative $2-\mathrm{RDP}$ levels and NAN values were respectively decreased by $10 \%$ and increased by $20 \%$ (see Table 6 ). Observed ; Exp. 1; $\square$ Exp. 2; * Exp. 3.

Using the prediction models for NAN and starch passage to the duodenum, predictions were made for typical scenarios expected with feedlot diets (Table 8). The ME content of the diet was set at $12 \mathrm{MJ} / \mathrm{kg} \mathrm{DM}$ and the OM intake at $8 \mathrm{~kg} /$ day, but the other variables were varied according to what might be encountered in different feedlot dietary compositions. The protein content was varied from 11 to $13 \%$, starch content from 20 to 35 and to $50 \%$, the RDP from 60 to $70 \%$, the $\mathrm{OMD}_{\mathrm{R}}$ from 60 to $80 \%$ and the St. $\mathrm{D}_{\mathrm{R}}$ from 70 to $90 \%$. The predictions indicate that within protein and starch contents, the highest availability of amino acids and starch at the duodenum can be expected with either 60 or $70 \%$ RDP at $60 \%$ $\mathrm{OMD}_{\mathrm{R}}$ and at $70 \%$ St. $\mathrm{D}_{\mathrm{R}}$. The amino acid contribution to the total will be more with $60 \%$ RDP than with $70 \%$ RDP, but this will be compensated for by more starch with the $70 \%$ RDP diet. Thus, provided amino acid availability is not limiting, one can expect similar growth performance on these two scenarios.

Across dietary starch contents, the maximum amino acid plus starch availability of the $11 \%$ protein and $35 \%$ starch diet ( 1.63 and $1.61 \mathrm{~kg} /$ day) may give better performance than 
Table 7 Prediction models for starch passage to the duodenum $(\mathrm{kg} / \mathrm{d})$ and postruminal starch digestion (\% of starch intake)

\begin{tabular}{lllccc}
\hline Independent variable & Parameter & Value $\pm S D$ & $t$-value & PR $\geq \mathrm{F}$ & \\
\hline Starch passage (kg/d) & Intercept & $0.267 \pm 0.103$ & 2.609 & 0.0111 & $n=74$ \\
& ME (MJ/kg) & $-0.020 \pm 0.009$ & -2.234 & 0.0254 & $r^{2}=0.97$ \\
& RDP (\%) & $0.032 \pm 0.001$ & 22.730 & 0.0001 & $S D=60 \mathrm{~g} / \mathrm{d}$ \\
& Starch intake (kg/d) & $0.152 \pm 0.009$ & 17.525 & 0.0001 & $C V \%=13.11$ \\
& RDP.St.D $(\%)^{1}$ & $-0.0004 \pm 0.00001$ & -34.064 & 0.0001 & \\
Starch digested (\%) & Intercept & $12.95 \pm 1.571$ & 8.241 & 0.0001 & $n=74$ \\
& ME (MJ/kg) & $0.346 \pm 0.135$ & 2.562 & 0.0126 & $r^{2}=0.991$ \\
& RDP (\%) & $1.156 \pm 0.021$ & 54.20 & 0.0001 & $S D=0.96 \%$ \\
& RDP.St. R $_{\mathrm{R}}(\%)$ & $-0.014 \pm 0.0002$ & -76.62 & 0.0001 & $C V \%=6.12$ \\
\hline
\end{tabular}

${ }^{1}$ RDP.St. $D_{R}=$ Interaction between RDP (\%) and starch fermented in the rumen as \% of total starch digested $\left(S t . D_{R}\right)$

the maximum amino acid and starch availability of the $11 \%$ protein $-50 \%$ starch diet $(1.72$ and $1.70 \mathrm{~kg} /$ day $)$, because amino acids in the combined availability of the latter diet may be insufficient (126 and $116 \mathrm{~g} \mathrm{NAN} / \mathrm{d} v s 143$ and $133 \mathrm{~g}$ NAN/d - Table 8).

Table 8 Prediction of NAN and starch available for postruminal digestion. Assumption: $\mathrm{OM}$ intake of steer is $8 \mathrm{~kg} / \mathrm{d}$ and the dietary energy content is $12 \mathrm{MJ} \mathrm{ME/}$ $\mathrm{kg} \mathrm{DM}$

\begin{tabular}{|c|c|c|c|c|c|c|c|}
\hline $\begin{array}{l}\text { Protein } \\
\%\end{array}$ & $\begin{array}{c}\text { Starch } \\
\%\end{array}$ & $\begin{array}{c}\text { RDP } \\
\%\end{array}$ & $\begin{array}{c}\mathrm{OMD}_{\mathrm{R}} \\
\%\end{array}$ & $\begin{array}{c}\text { St.D } \\
\%\end{array}$ & $\begin{array}{c}\text { NAN } \\
\mathrm{g} / \mathrm{d}\end{array}$ & $\begin{array}{c}\mathrm{Starch}_{\mathrm{D}} \\
\mathrm{kg} / \mathrm{d}\end{array}$ & $\begin{array}{c}{ }^{1} \mathrm{AA}+\mathrm{Starch}_{\mathrm{D}} \\
\mathrm{kg} / \mathrm{d}\end{array}$ \\
\hline \multirow[t]{4}{*}{11} & 20 & 60 & 60 & 70 & 161 & 0.535 & 1.54 \\
\hline & & & 80 & 90 & 140 & 0.055 & 0.93 \\
\hline & & 70 & 60 & 70 & 151 & 0.575 & 1.52 \\
\hline & & & 80 & 90 & 127 & 0.015 & 0.81 \\
\hline \multirow[t]{4}{*}{13} & 20 & 60 & 60 & 70 & 173 & 0.535 & 1.62 \\
\hline & & & 80 & 90 & 153 & 0.055 & 1.01 \\
\hline & & 70 & 60 & 70 & 163 & 0.575 & 1.59 \\
\hline & & & 80 & 90 & 139 & 0.015 & 0.88 \\
\hline \multirow[t]{4}{*}{11} & 35 & 60 & 60 & 70 & 143 & 0.735 & 1.63 \\
\hline & & & 80 & 90 & 123 & 0.255 & 1.02 \\
\hline & & 70 & 60 & 70 & 133 & 0.775 & 1.61 \\
\hline & & & 80 & 90 & 109 & 0.215 & 0.90 \\
\hline \multirow[t]{4}{*}{13} & 35 & 60 & 60 & 70 & 156 & 0.735 & 1.71 \\
\hline & & & 80 & 90 & 135 & 0.255 & 1.10 \\
\hline & & 70 & 60 & 70 & 145 & 0.775 & 1.68 \\
\hline & & & 80 & 90 & 122 & 0.215 & 0.98 \\
\hline \multirow[t]{4}{*}{11} & 50 & 60 & 60 & 70 & 126 & 0.936 & 1.72 \\
\hline & & & 80 & 90 & 105 & 0.456 & 1.11 \\
\hline & & 70 & 60 & 70 & 116 & 0.976 & 1.70 \\
\hline & & & 80 & 90 & 91.8 & 0.416 & 0.99 \\
\hline \multirow[t]{4}{*}{13} & 50 & 60 & 60 & 70 & 138 & 0.936 & 1.80 \\
\hline & & & 80 & 90 & 118 & 0.456 & 1.19 \\
\hline & & 70 & 60 & 70 & 128 & 0.976 & 1.78 \\
\hline & & & 80 & 90 & 104 & 0.416 & 1.07 \\
\hline
\end{tabular}

${ }^{1} \mathrm{AA}+\mathrm{Starch}_{\mathrm{D}}=$ Amino acids $(\mathrm{NAN} \times 6.25)$ plus starch availability at the duodenum
During the statistical analysis, it became evident that individual variation in NAN and starch passage to the duodenum was substantial. Consequently, individual variation was investigated further, using the data of Exp. 3 where treatment differences mainly were not significant. The fermentation of $\mathrm{OM}$ in the rumen as proportion of the total $\mathrm{OM}$ digested $\left(O M D_{R}\right)$ was used as reference. This is a function of rumen retention time which is partly determined by individual variation. Because rumen retention time affects $O M D_{R}$, intake is expected to also affect $\mathrm{OMD}_{\mathrm{R}}$, but in Exp. 3 the correlation $\left(r^{2}\right.$ $=0.007)$ was not significant. Therefore, the differences in $\mathrm{OMD}_{\mathrm{R}}$ were apparently largely the result of inherent variability (Table 9 ). $O M D_{R}$ was significantly negatively associated with NAN $\left(r^{2}=0.37\right)$ and starch $\left(r^{2}=0.77\right)$ passage to the duodenum, i.e., more NAN and starch passed to the duodenum when proportionally less OM was fermented in the rumen. The net effect of the variation between animals on the same diet was that more than double the amount of amino acids and starch were in some animals available for absorption than in others (Table 9).

\section{Discussion}

The results are discussed across experiments and in the context of the multivariate models rather than the findings in

Table 9 Animal variation in proportion of OM fermented in the rumen $\left(O M D_{R}\right)$ and its effect on NAN and starch passage to the duodenum. Average of the four treatments in Exp 3.

\begin{tabular}{lcccc}
\hline Steer No. & OMD $_{\mathrm{R}} \%$ & NAN g/d & Starch kg/d & AA + Starch $^{1} \mathrm{~kg} / \mathrm{d}$ \\
\hline 15 & $85.0^{\mathrm{c}}$ & $51.7^{\mathrm{ab}}$ & $0.34^{\mathrm{a}}$ & 0.66 \\
5 & $80.5^{\mathrm{bc}}$ & $37.4^{\mathrm{a}}$ & $0.49^{\mathrm{ab}}$ & 0.72 \\
3 & $76.1^{\mathrm{abc}}$ & $44.0^{\mathrm{a}}$ & $0.55^{\mathrm{abc}}$ & 0.83 \\
13 & $72.7^{\mathrm{abc}}$ & $70.1^{\mathrm{bc}}$ & $0.79^{\mathrm{bc}}$ & 1.23 \\
9 & $72.1^{\mathrm{abc}}$ & $65.2^{\mathrm{bc}}$ & $0.67^{\mathrm{abc}}$ & 1.08 \\
10 & $71.8^{\mathrm{abc}}$ & $90.8^{\mathrm{d}}$ & $1.00^{\mathrm{c}}$ & 1.57 \\
8 & $70.7^{\mathrm{a}}$ & $67.7^{\mathrm{bc}}$ & $0.84^{\mathrm{bc}}$ & 1.26 \\
12 & $66.4^{\mathrm{a}}$ & $78.4^{\mathrm{cd}}$ & $0.96^{\mathrm{c}}$ & 1.45 \\
$\mathrm{SD}$ & 1.43 & 2.26 & 0.05 & - \\
\hline
\end{tabular}

${ }^{1} \mathrm{AA}+$ Starch $=$ Amino acids $(\mathrm{NAN} \times 6.25)$ plus starch

${ }^{a, b}$ Values in the same column with different superscripts differ $(p \leq 0.05)$ 
Exp. 1, 2 and 3 per se.

With more starch in the diet more passed to the duodenum and a higher percentage of dietary starch was digested in the lower digestive tract. This agrees with the reports of Owens et al. (1986) and Hill et al. (1991). They found linear relationships between starch entering the duodenum and starch digested in the small and large intestine. The relationship in the present study was also linear, with postruminal starch digestion increasing from $50 \%$ when $0.24 \mathrm{~kg}$ entered the duodenum on the low energy diet in Exp. 1 (Table 1) to $86 \%$ on the soft normal-lysine cultivar in Exp. 3 (Table 3) when 1.06 $\mathrm{kg}$ entered the duodenum. More starch is expected to pass to the duodenum on whole maize than milled maize (Hale, 1973; Galyean et al., 1981); therefore, the differences between Exp. 1, 2 and 3 in the proportion of starch entering the duodenum are not solely accounted for by differences in dietary starch contents, but may also be due to differences in starch sources and processing methods.

Whereas starch passage to the duodenum and postruminal starch digestion increased with more starch in the diet, NAN passage to the duodenum decreased. Postruminal NAN digestibility was not affected by any factors measured, and averaged $69 \pm 1.5 \%$ across diets. This corresponds with NAN digestibilities reported by Streeter \& Mathis (1995). They showed a slight increase in NAN digestibility to about $72 \%$ when fish meal is part of the escape protein; the results in Exp. 2 (Table 2) of Meissner \& Du Plessis (1992), however, do not correspond, but their results are consistent with the contention of Owens et al. (1984).

NAN passage to the duodenum on high quality forage diets is 1 to $2 \mathrm{~g} / \mathrm{MJ}$ ME intake (Beever et al. 1987). This figure is usually lower with high energy (feedlot) diets, because of reduced ruminal dilution rate (Owens et al., 1984). In the present investigation NAN passage decreased from $1.6 \mathrm{~g} / \mathrm{MJ}$ ME intake on the two diets in Exp. 1 (Table 1) to about $1.2 \mathrm{~g} /$ MJ ME intake on the diets of Exp. 2 (Table 2) and to $0.9 \mathrm{~g} / \mathrm{MJ}$ ME intake for the diets in Exp. 3 (Table 3). The decline in NAN passage is apparently associated with lower microbial protein production on the higher starch diets.

Ruminal $\mathrm{pH}$ was found to decline in association with the higher starch fermentation in the rumen (Figure 1). The $\mathrm{pH}$ in Exp. 3 was consistently lower than 6 even though buffers were included in the diets. Henning et al. (1993) showed that low $\mathrm{pH}$ depresses microbial growth and efficiency.

The negative effect of high starch contents on NAN passage to the duodenum is illustrated further in the prediction models of Tables 4 and 5. It would appear that for NAN optimization, starch in maize-based feedlot diets should not exceed $50 \%$, although the degree of maize processing will have a modifying effect. The calculations in Table 8 support this contention as they indicate that NAN availability may become limiting unless the $\mathrm{CP} \%$ in the diet is increased.

The prediction models (Tables 4 and 5) indicate that $\mathrm{N}$ intake and therefore protein content of the diet are the primary supporters of high NAN passage. In contrast, RDP\% within the limits of practical South African feedlot diets, have little or no effect on NAN passage. The results of Meissner \& Du Plessis (1992), Streeter \& Mathis (1995) and Meissner \& Du Preez (1996) apparently support this conclusion. The effect of RDP is apparently rather through its effect of chang- ing rumen fermentation and thereby affecting the proportion of OM that is apparently digested in the rumen. Lower RDP levels will tend to decrease rumen fermentation, thereby allowing more protein unfermented through to the duodenum. In the present investigation this effect resulted in $10 \mathrm{~g} \mathrm{NAN} /$ day more (Table 8). Because the proportion of OM and therefore starch that is apparantly fermented in the rumen is reduced, more starch will also pass to the duodenum as predicted by the models in Table 7 and shown in Table 8 . Whether these alterations in $\mathrm{OMD}_{\mathrm{R}}$ and St. $\mathrm{D}_{\mathrm{R}}$ coincide with a change in rumen retention time should be investigated, but it seems highly probable.

Individual variation in rumen retention time and, as a result $\mathrm{OMD}_{\mathrm{R}}$, may be substantial (Orskov et al., 1971; Smuts et al., 1995). It also is a heritable characteristic (Smuts et al., 1995). The results in Table 9 indicate that steers with low $O M D_{R}$ may benefit from the availability of more amino acids and starch in the small intestine, if it is assumed that starch digestion in the small intestine is beneficial, which is not generally true (Theurer, 1986). With more absorbed amino acids and glucose, both the supply to and efficiency of utilization of these nutrients at the tissue level should be improved (Leng, 1982; Owens et al., 1984). Meissner and co-workers (1995) showed that feedlot steers, gaining in excess of $2 \mathrm{~kg} /$ day resulting in a feed conversion ratio of $4 \mathrm{~kg} \mathrm{DM} / \mathrm{kg}$ gain, rarely have high feed intakes. Perhaps these animals have short rumen retention times which enhances postruminal nutrient supply and absorption. Future work should address this hypothesis.

The models to predict NAN and starch availability at the duodenum both proved satisfactorily accurate (Figure 2) and robust (Table 6, Figure 3), and because they resulted from divergent feeding systems, should apply across most feeding systems used in southern Africa. The extended data set of the three trials also confirmed the pointers from the first paper (Meissner \& Du Preez, 1996).

\section{References}

BEEVER, D.E., LOSADA, H.R., GALE, D.L., SPOONER, M.C. \& DHANOA, M.S., 1987. The use of monensin or formaldehyde to control the digestion of the nitrogenous constituents of perennial ryegrass (Lolium perenne cv Melle) and white clover (Trifolium repens $\mathrm{cv}$ Blanca) in the rumen of cattle. Br. J. Nutr. 57, 57

GALYEAN, M.L., WAGNER, D.G. \& OWENS, F.N., 1981. Dry matter and starch disappearance of corn and sorghum as influenced by particle size and processing. J. Dairy Sci. 64, 1804

HALE, W.H., 1973. Influence of processing on the utilisation of grains (starch) by ruminants. J. Anim. Sci. 37, 1075.

HENNING, P.H., STEYN, D.G. \& MEISSNER, H.H., 1993. Effect of synchronization of energy and nitrogen supply on ruminal characteristics and microbial growth. J. Anim. Sci. 71, 2516.

HILL, T.M., SCHMIDT, S.P., RUSSELL, R.W., THOMAS, E.E. \& WOLFE, D.F., 1991. Comparison of urea treatment with established methods of sorghum grain preservation and processing on site and extent of starch digestion by cattle. J. Anim. Sci. 69, 4570 .

LENG, R.A., 1982. Modification of rumen fermentation. In: Nutritional limits to animal production from pastures. Ed., Hacker, J.B. Commonwealth Agricultural Bureaux. p. 427.

MACRAE, J.C. \& ULYATT, M.J., 1974. Quantitative digestion of fresh herbage by sheep. 1. The sites of digestion of organic matter, energy, readily-fermentable carbohydrate, structural 
carbohydrate and lipid. J. Agric. Sci. Camb. 82, 309.

MEISSNER, H.H. \& DU PLESSIS, P.C., 1992. Protein and starch digestion in steers fed feedlot diets differing in extent of protein degradation. S.Afr.J. Anim. Sci. 22, 137.

MEISSNER, H.H. \& DU PREEZ, H.P.F., 1996. Ruminal and postruminal digestion of dietary protein and starch in steers. 1. Effects of protein concentration, degradation of protein and energy content of the diet. S.Afr.J. Anim. Sci. 26, 59.

MEISSNER, H.H., SMUTS, M. \& COERTZE, R.J., 1995. Characteristics and efficiency of fast-growing feedlot steers fed different dietary energy concentrations. J. Anim. Sci. 73, 931.

ØRSKOV, E.R., FRASER, C. \& McDONALD, I., 1971. Digestion of concentrates in sheep. 3. Effect of rumen fermentation of barley and maize diets on protein digestion. Br. J. Nutr. 26, 477.

OWENS, F.N., WEAKLEY, D.C. \& GOETSCH, A.L., 1984.

Modification of rumen fermentation and digestion in the rumen.
In: Herbivore nutrition in the subtropics and tropics. Eds, Gilchrist, F.M.C. \& Mackie, R.I. The Science Press (Pty) Ltd, Craighall, South Africa. p 435.

OWENS, F.N., ZINN, R.A. \& KIM, Y.K., 1986. Limits to starch digestion in the ruminant small intestine. J. Anim. Sci. 63, 1634

SAS, 1985. SAS User's Guide. Institute Inc. Raleigh, North Carolina.

SMUTS, M., MEISSNER, H.H. \& CRONJÉ, P.B., 1995. Retention time of digesta in the rumen: Its repeatability and relationship with wool production of Merino rams. J. Anim. Sci. 73, 206.

STREETER, M.N. \& MATHIS, M.J., 1995. Effect of supplemental fish meal protein on site and extent of digestion in beef steers. $J$. Anim. Sci. 73, 1196.

THEURER, C.B., 1986. Grain processing effects on starch utilization by ruminants. J. Anim. Sci. $63,1649$. 